\title{
REVIEW ARTICLE \\ DUKUNGAN KELUARGA MENINGKATKAN KUALITAS HIDUP LANSIA
}

\author{
May Dwi Yuri Santoso \\ RSUD dr. Soehadi Prijonegoro Sragen \\ maydwiyurisantoso@gmail.com
}

\begin{abstract}
Family support is a supporting factor or a supporting factor for a person's behavior and lifestyle so that it influences the health status and quality of life of the elderly. The purpose of this literature is to review various literature on family support for the quality of life of the elderly so that it can be used as information data to make the life of the elderly more meaningful that there is encouragement to live with the life they live every day caused by family support. The method used is a scientific electronic bibliographic database of articles published through Google Scholar with 1,370,000 articles, Pubmed with 9,376 articles, Microsoft Academic 60 articles and from Google Scholar as many as 655 articles, then 10 articles were selected. The results of a review of 10 selected articles stated that family support improved the quality of life for the elderly. Families play an important role in the concept of healthy pain in their elderly family members, the family provides direct care for sick family members, the family is a support system physically, psychologically, socially and environmentally in improving the quality of life for the elderly.
\end{abstract}

\section{Keywords : family support, quality of life, elderly}

Abstraksi. Dukungan keluarga merupakan supporting factors atau faktor pendukung bagi perilaku serta gaya hidup seseorang sehingga berpengaruh terhadap status kesehatan dan kualitas hidup lansia. Tujuan literatur ini adalah untuk mengulas berbagai literatur mengenai dukungan keluarga terhadap kualitas hidup lansia sehingga dapat dijadikan sebagai data informasi untuk menjadikan kehidupan lansia menjadi lebih berarti adanya dorongan untuk hidup dengan kehidupan yang mereka jalani setiap harinya disebakan oleh dukungan dari keluarga. Metode yang digunakan adalah database bibliografi elektronik ilmiah dari artikel yang telah dipublikasikan melalui Google Scholar sebanyak 1.370.000 artikel, Pubmed sebanyak 9.376 artikel, Microsoft Academic 60 artikel dan dari Google Cendekia sebanyak 655 artikel, kemudian dipilih 10 artikel. Hasil review dari 10 artikel yang telah dipilih menyatakan dukungan keluarga meningkatkan kualitas hidup lansia. Keluarga sangat berperan penting dalam konsep sehat sakit pada anggota keluarganya yang sudah lansia, keluarga memberikan perawatan secara langsung terhadap anggota keluarganya yang sakit, keluarga merupakan sebuah sistem pendukung secara fisik, psikologis, sosial dan lingkungan pada peningkatan kualitas hidup lansia.

\section{Kata kunci : dukungan keluarga, kualitas hidup, lansia}

\section{PENDAHULUAN}

Perubahan menua adalah proses normal, biologis, dan universal (Tel, 2013). Jumlah lansia di dunia saat ini mengalami peningkatan yang cukup signifikan sejak 6 dekade terakhir dari $8 \%$ hingga $10 \%$ dari total jumlah penduduk dunia (Beard, 2012). Kurang lebih 1 dari 4 lansia atau 1 milyar lansia dan diperkirakan pada tahun 2025 meningkat menjadi 1,6 milyar lansia di dunia akan terserang berbagai macam penyakit (Wahdah, Nurul, 2011). Keluarga berfungsi dalam mrmprtahankn 
kesehatan bagi lansia atau sebagai support system utama. Dukungan keluarga merupakan (supporting factors) faktor pendukung yang berpengaruh terhadap gaya hidup dan perilaku seseorang sehingga berpengaruh dalam status kesehatan dan kualitas hidup (Maryam, Resnayati, Riasmini, Sari, 2018).

Dukungan keluarga merupakan salah satu faktor yang mempengaruhi kualitas hidup lansia. Dukungan keluarga adalah keluarga yang mempunyai perilaku melayani dengan baik kepada lansia dalam hal informasi, penilaian atau penghargaan, instrumental dan emosional (Fadilah, Bachri, Sutrisno, Angelia, 2015).

Kualitas hidup di kalangan lansia adalah kesehatan fisik, kesehatan psikologis, sosial pada kondisi fungsional dan kondisi lingkungan lansia. Tingkat kemandirian, kondisi fisik, psikologis, sosial dan lingkungan berpengaruh terhadap kualitas kehidupan manusia. Kualitas hidup lansia menurun disebakan oleh lansia mengalami banyak keterbatasan dalam hidup, sehingga lansia membutuhkan dukungan dari keluarga, pasangan dan masyarakat untuk meningkatkan kualitas hidup. Lingkungan sekitar memiliki dampak penting dan berkontribusi terhadap lingkungan fisik dan sosial bagi lansia. Tempat tinggal sebagai komponen penting dari komunitas yang kohesif dan produktif sebagai tempat berinteraksi satu sama lain anggota keluarga dalam hal tingkat kepercayaan, norma timbal balik antara individu yang memasuki modal sosial (Yuliati, Baroya, Ririanty, 2014).

Dukungan keluarga berpengaruh terhadap kesejahteraan atau kualitas hidup pada lansia dengan hasil dari beberapa penelitian menunjukkan hasil yang positif. Tujuan literatur ini adalah untuk mengulas berbagai literatur mengenai dukungan keluarga terhadap kualitas hidup lansia sehingga dapat dijadikan sebagai data informasi untuk menjadikan kehidupan lansia menjadi lebih berarti, adanya dorongan untuk hidup lebih bekualitas yang dijalaninya setiap hari dengan adanya dukungan dari keluarga.

\section{METODE PENELITIAN}

Metode penelitian dilakukan dengan metodologi sistematik dan sesuai dengan pedoman pelaporan Preferred Reporting Items for Systematic reviews and MetaAnalyses (PRISMA) (Moher, Liberati, Tetzlaff, Altman, 2009). Penulis mencari literatur yang dipublikasikan di database bibliografi elektronik ilmiah yang digunakan dalam bahasa inggris dari Google Scholar, Pubmed, Microsoft Academic dan dalam bahasa Indonesia dari Google Cendekia. 


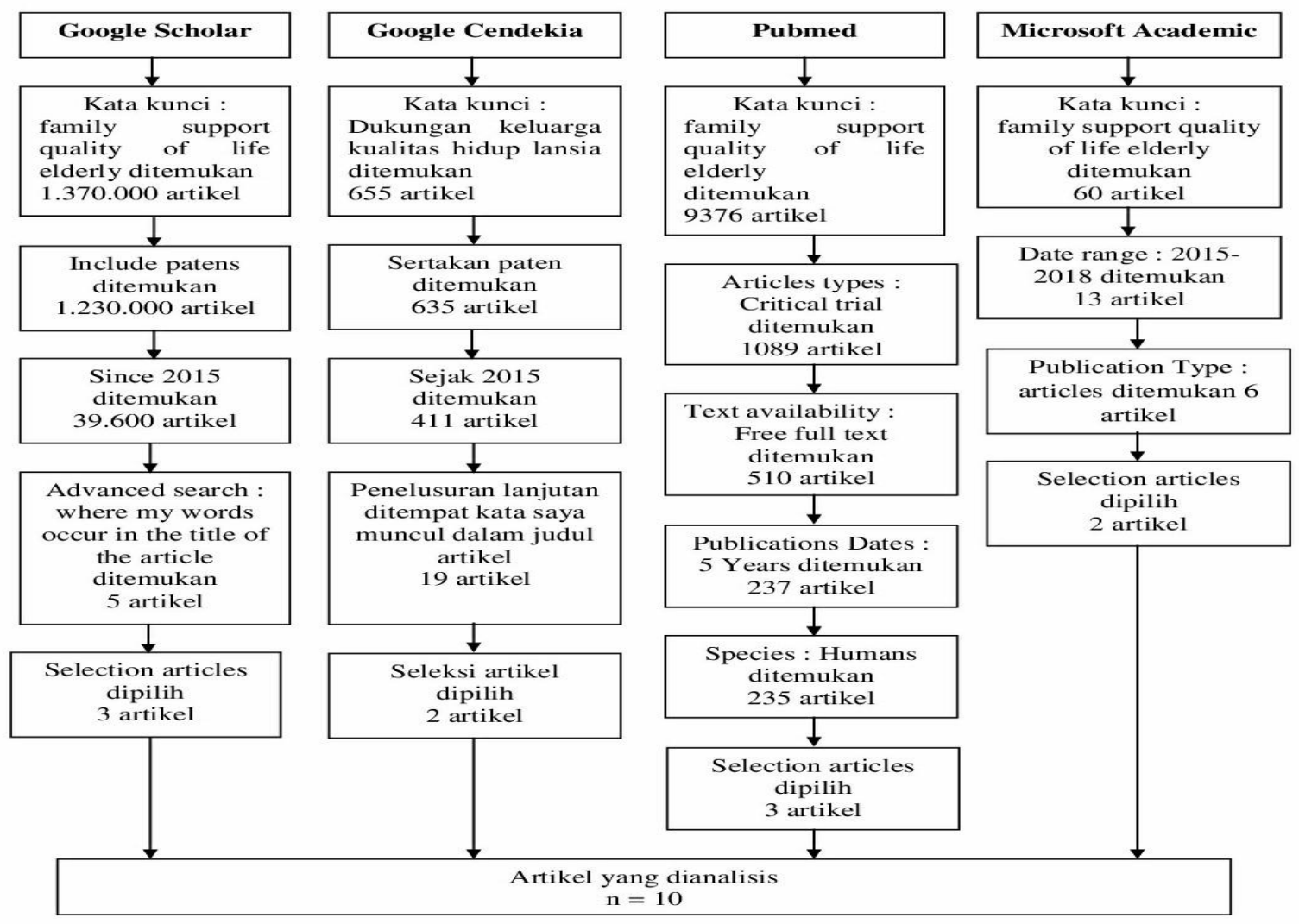

Gambar 1. Flowchart Proses Pencarian

Kata kunci (keyword) yang digunakan adalah untuk artikel dalam bahasa Inggris yaitu "Family Support-Quality Of LifeElderly" dalam bahasa Indonesia "Dukungan Keluarga-Kualitas HidupLansia" Hasil pencarian ditemukan pada Google Scholar sebanyak 1.370 .000 artikel, Pubmed sebanyak 9.376 artikel, Microsoft Academic 60 artikel dan dari Google Cendekia sebanyak 655 artikel.

Jurnal yang ditemukan dispesifikkan berdasarkan kriteria inklusi yaitu artikel artikel dipublikasikan dalam rentang waktu 2015-2019 ditemukan pada Google Scholar sebanyak 39.600 artikel, Pubmed sebanyak 237 artikel, Microsoft Academic 13 artikel dan dari Google Cendekia sebanyak 411 artikel.

Dilanjutkan menyeleksi artikel sama (duplicate article) yang diterbitkan pada Google Scholar, Pubmed, Microsoft Academic dan Google Cendekia, penyeleksian berdasarkan kesesuain judul artikel dengan tujuan review artikel, Kriteria Inklusi: a) Artikel menggunakan rancangan kuantitatif, kualitatif maupun mix method, b) Fulltext artikel dapat diakses, c) Artikel diterbitkan dari tahun 2015-2019. Kriteria Eksklusi: a) Metode tidak jelas, b) Artikel merupakan sistematic review, c) Editorial tidak jelas, d) Tidak terlihat korelasi dalam hasil.

Cara penelusuran artikel dapat dilihat dari gambar 1. Selanjutnya melakukan screening berdasarkan seleksi judul, abstrak dan fulltext diperoleh 10 artikel. Pada tahap akhir seleksi ditemukan 10 artikel menggunakan teknik snow balling sesuai kriteria inklusi dan eksklusi.

\section{HASIL PENELITIAN}

Dari 10 artikel diperoleh 7 metode kuantitatif : 3 penelitian dengan desain cross sectional, 1 quasi experiment 
dengan kontrol group, 2 observasional analitik dengan desain cross sectional, 3 metode mix method : 2 deskriptif korelational dengan kuantitatif dan kualitatif desain, 1 deskriptif exproratory dengan kuantitatif dan kaulitatif dan 1 korelational dengan desain cross sectional. Studi dilakukan di berbagai Negara antara lain Brazil, Cina, India dan Indonesia. Sampel yang digunakan adalah lansia yang mendapatkan dukungan keluarga dan hubungannya dengan kualitas hidup maka dipilih 8 artikel bahasa Inggris dan 2 artikel bahasa Indonesia yang akan dianalisis.

Penelitian yang dilakukan di berbagai Negara menunjukkan dukungan keluarga memiliki pengaruh terhadap kualitas hidup lansia. Penelitian di Brazil terhadap lansia dengan gejala depresi sebanyak 59 orang dan lansia tanpa gejala depresi sebanyak 61 orang diperoleh hasil lansia dengan gejala depresi memiliki kualitas hidup yang lebih rendah dalam domain hubungan sosial dengan tingkat keterlibatan atau dukungan keluarga yang rendah dalam penyelesaian masalah daripada orang-orang tanpa gejala depresi (Silva, Medeiros, Guerra, Ferreira, Júnior, 2017).

Penelitian di Cina terhadap 1.456 orang lansia berusia 60 tahun ke atas diperoleh hasil dukungan keluarga dari segi keuangan meningkatkan kualitas hidup lansia kecuali untuk peningkatan risiko penyakit jantung dalam jangka menengah (Liu, Xiao, Cai, Shuzhuo Li, 2015).

Penelitian di Brazil terhadap 138 lansia : 69 dengan gejala depresi dan 69 lansia tidak dengan gejala depresi di Negara bagian Rio Grande do Norte,
Brazil diperoleh hasil faktor yang mempengaruhi kualitas hidup lansia kondisi ekonomi yang rendah, terjadinya penyakit penyerta dan kurangnya bantuan atau dukungan keluarga (de Araújo, Barbosa, de Menezes, de Medeiros, de Araújo, de Medeiros, 2016).

Penelitian di Indonesia terhadap 30 orang lansia untuk intervensi dan 30 orang lansia untuk kontrol di Puskesmas Cipayung Jakarta Timur, Indonesia diperoleh hasil program intervensi dukungan keluarga berpengaruh terhadap kualitas hidup lansia dengan hipertensi (Maryam, Resnayati, Riasmini, Sari, 2018).

Penelitian di Indonesia terhadap 150 orang lansia dengan umur 60-74 tahun di Sidorejo, Salatiga, Jawa Tengah, Indonesia diperoleh hasil secara langsung kualitas hidup lansia dipengaruhi oleh pendapatan, dukungan keluarga, dan efikasi diri, sedangkan secara tidak langsung kualitas hidup dipengaruhi oleh pendidikan, status pekerjaan, modal sosial, dan status tempat tinggal (Kadarwati, Soemanto, Murti, 2017).

Penelitian di Indonesia terhadap 54 orang lansia kelompok perlakuan di panti wreda dan kelompok kontrol sebanyak 164 orang lansia di posyandu lansia di Surakarta, Jawa Tengah, Indonesia diperoleh hasil kualitas hidup lansia yang lebih baik secara langsung ditingkatkan oleh dukungan teman sebaya yang kuat, dukungan keluarga yang kuat, demensia ringan dan menikah. Secara tidak langsung meningkat dengan dukungan teman sebaya yang kuat dan hidup bersama keluarga (Suwarni, Soemanto, Sudiyanto,

2018). 
Tabel 1. Hasil Analisis Literature Review

\begin{tabular}{|c|c|c|c|c|c|}
\hline No & $\begin{array}{c}\text { Nama peneliti } \\
\text { dan tahun } \\
\text { publikasi }\end{array}$ & $\begin{array}{l}\text { Rancangan } \\
\text { penelitian }\end{array}$ & $\begin{array}{l}\text { Sumber data dan } \\
\text { metode pengumpulan } \\
\text { data }\end{array}$ & $\begin{array}{l}\text { Jumlah } \\
\text { sampel atau } \\
\text { informan }\end{array}$ & Hasil temuan kunci \\
\hline 1 & $\begin{array}{l}\text { Silva VdL, } \\
\text { Medeiros } \\
\text { CACXd, } \\
\text { Guerra GCB, } \\
\text { Ferreira PHA, } \\
\text { Júnior RFdA, } \\
2017 \text { tahun } \\
2017\end{array}$ & $\begin{array}{l}\text { Kuantitatif } \\
\text { cross sectional }\end{array}$ & $\begin{array}{l}\text { Kuesioner } \\
\text { Mini-Mental State } \\
\text { Examination, the } \\
\text { short version of the } \\
\text { Geriatric Depression } \\
\text { Scale, kuesioner a } \\
\text { clinical socio- } \\
\text { demographic, } \\
\text { kuesioner the } \\
\text { abbreviated version } \\
\text { of the World Health } \\
\text { Organisation Quality } \\
\text { of Life questionnaire, } \\
\text { kuesioner } \\
\text { the Family Assessmen } \\
t \quad \text { Device dan } \\
\text { kuesioner the Patient } \\
\text { Satisfaction with } \\
\text { Mental Health } \\
\text { Services Rating Scale }\end{array}$ & $\begin{array}{ll}\text { Lansia } & \\
\text { dengan } & \\
\text { gejala } & \\
\text { depresi } & \\
\text { sebanyak } & 59 \\
\text { orang dan } \\
\text { lansia tanpa } \\
\text { gejala } \\
\text { depresi } \\
\text { sebanyak } & 61 \\
\text { orang } & \\
\text { diberikan } & \\
\text { kepada } & \\
\text { lansia } & \text { di } \\
\text { Negara } \\
\text { bagian Rio } \\
\text { Grande do } \\
\text { Norte, Brazil }\end{array}$ & $\begin{array}{l}\text { Lansia dengan gejala } \\
\text { depresi memiliki kualitas } \\
\text { hidup yang lebih rendah } \\
\text { dalam domain hubungan } \\
\text { sosial dengan tingkat } \\
\text { keterlibatan } \\
\text { dukungan keluarga yang } \\
\text { rendah atalam } \\
\text { penyelesaian masalah } \\
\text { daripada orang-orang } \\
\text { tanpa gejala depresi. }\end{array}$ \\
\hline 2 & $\begin{array}{l}\text { Liu H, Xiao Q, } \\
\text { Cai Y, Y, } \\
\text { Shuzhuo } \\
\text { Li tahun } 2015\end{array}$ & Cross sectional & $\begin{array}{lr}\text { Kuesioner } & \text { kualitas } \\
\text { hidup dan } & \text { resiko } \\
\text { kematian } & \text { lansia, } \\
\text { kuesioner } & \text { dukungan } \\
\text { keluarga } & \end{array}$ & $\begin{array}{l}\text { 1.456 orang } \\
\text { lansia } \\
\text { berusia } 60 \\
\text { tahun ke atas } \\
\text { di wilayah } \\
\text { Chaohu } \\
\text { Negara Cina }\end{array}$ & 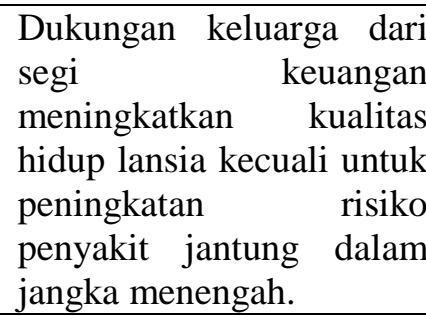 \\
\hline 3 & $\begin{array}{l}\text { de Araújo } \\
\text { AA, Barbosa } \\
\text { RA, de } \\
\text { Menezes } \\
\text { MS, de } \\
\text { Medeiros } \\
\text { II, de Araújo } \\
\text { RF Jr, de } \\
\text { Medeiros CA } \\
\text { tahun 2016 }\end{array}$ & $\begin{array}{l}\text { Kuantitatif } \\
\text { studi cross } \\
\text { sectional }\end{array}$ & $\begin{array}{l}\text { Kuesioner quality of } \\
\text { life (World Health } \\
\text { Organization Quality } \\
\text { of Life abbreviated- } \\
\text { WHOQOL-bref) dan } \\
\text { kuesioner inventory of } \\
\text { perception } \\
\text { of family support. }\end{array}$ & $\begin{array}{l}138 \text { lansia : } \\
69 \text { dengan } \\
\text { gejala } \\
\text { depresi dan } \\
69 \text { lansia } \\
\text { tidak dengan } \\
\text { gejala } \\
\text { depresi di } \\
\text { Negara } \\
\text { bagian Rio } \\
\text { Grande do } \\
\text { Norte, Brazil }\end{array}$ & $\begin{array}{l}\text { Faktor yang } \\
\text { mempengaruhi kualitas } \\
\text { hidup lansia kondisi } \\
\text { ekonomi yang rendah, } \\
\text { terjadinya penyakit } \\
\text { penyerta dan } \\
\text { kurangnya bantuan atau } \\
\text { dukungan keluarga }\end{array}$ \\
\hline 4 & $\begin{array}{l}\text { Maryam RS, } \\
\text { Resnayati Y, } \\
\text { Riasmini NM, } \\
\text { Sari CWM } \\
\text { tahun } 2018\end{array}$ & $\begin{array}{l}\text { Quasi } \\
\text { experiment } \\
\text { dengan desain } \\
\text { control group }\end{array}$ & $\begin{array}{lr}\text { Kuesioner } & \text { dukungan } \\
\text { keluarga } & \text { dan } \\
\text { kuesioner } & \text { kualitas } \\
\text { hidup } & \end{array}$ & $\begin{array}{l}30 \text { orang } \\
\text { lansia untuk } \\
\text { intervensi } \\
\text { dan } 30 \text { orang } \\
\text { lansia untuk } \\
\text { kontrol di } \\
\text { Puskesmas } \\
\text { Cipayung } \\
\text { Jakarta } \\
\text { Timur, } \\
\text { Indonesia. }\end{array}$ & $\begin{array}{l}\text { Program intervensi } \\
\text { dukungan keluarga } \\
\text { berpengaruh terhadap } \\
\text { kualitas hidup lansia } \\
\text { dengan hipertensi }\end{array}$ \\
\hline
\end{tabular}




\begin{tabular}{|c|c|c|c|c|c|}
\hline 5 & $\begin{array}{l}\text { Kadarwati, } \\
\text { Soemanto } \\
\text { RB, Murti B } \\
\text { tahun } 2017\end{array}$ & $\begin{array}{l}\text { Studi } \\
\text { observasional } \\
\text { analiktik dengan } \\
\text { desain cross } \\
\text { sectional }\end{array}$ & $\begin{array}{l}\text { Kuesioner } \quad \text { dukungan } \\
\text { keluarga, kuesioner } \\
\text { modalitas sosial dan } \\
\text { kuesioner efikasi diri }\end{array}$ & $\begin{array}{lr}150 & \text { orang } \\
\text { lansia } & \text { dengan } \\
\text { umur } & 60-74 \\
\text { tahun } & \text { di } \\
\text { Sidorejo, } & \\
\text { Salatiga, Jawa } \\
\text { Tengah, } \\
\text { Indonesia. }\end{array}$ & \begin{tabular}{lr}
\multicolumn{3}{l}{ Pendapatan, dukungan } \\
keluarga, dan & efikasi \\
diri & berpengaruh \\
terhadap & kualitas \\
hidup secara langsung. & status \\
Pendidikan, & pekerjaan, \\
sosial, dan & status \\
tempat & tinggal \\
berpengaruh & terhadap \\
kualitas hidup & secara \\
tidak langsung.
\end{tabular} \\
\hline 6 & $\begin{array}{l}\text { Suwarni S, } \\
\text { Soemanto } \\
\text { RB, } \\
\text { Sudiyanto A } \\
\text { tahun } 2018\end{array}$ & $\begin{array}{l}\text { Studi } \\
\text { observasional } \\
\text { analitik dengan } \\
\text { cross sectional }\end{array}$ & $\begin{array}{l}\text { Kuesioner dukungan } \\
\text { keluarga, kuesioner } \\
\text { dukungan teman sebaya } \\
\text { dan kuesioner kualitas } \\
\text { hidup MMSE dan } \\
\text { WHO-QOL-BREF }\end{array}$ & $\begin{array}{l}54 \text { lansia } \\
\text { kelompok } \\
\text { perlakuan di } \\
\text { panti wreda } \\
\text { dan kelompok } \\
\text { kontrol } \\
\text { sebanyak } 164 \\
\text { orang dari } \\
\text { Posyandu } \\
\text { lansia di } \\
\text { Surakarta, } \\
\text { Jawa Tengah, } \\
\text { Indonesia. }\end{array}$ & $\begin{array}{l}\text { Kualitas hidup lansia } \\
\text { yang lebih baik secara } \\
\text { langsung ditingkatkan } \\
\text { oleh dukungan teman } \\
\text { sebaya yang kuat, } \\
\text { dukungan keluarga } \\
\text { yang kuat, demensia } \\
\text { ringan, dan menikah, } \\
\text { tidak rangsung } \\
\text { meningkat dengan } \\
\text { dukungan teman } \\
\text { sebaya yang kuat dan } \\
\text { hidup bersama } \\
\text { keluarga. }\end{array}$ \\
\hline 7 & $\begin{array}{l}\text { Harkirat } \mathrm{K}, \\
\text { Harleen } \quad \mathrm{K}, \\
\text { Mahalingam } \\
\text { V tahun } 2015\end{array}$ & $\begin{array}{l}\text { Deskriptif } \\
\text { korelasional } \\
\text { dengan } \\
\text { pendekatan } \\
\text { kuantitatif dan } \\
\text { kualitatif }\end{array}$ & 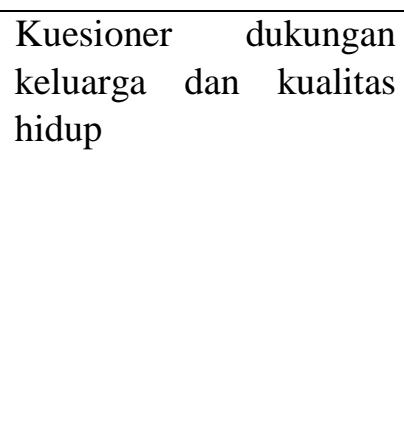 & $\begin{array}{l}213 \text { lansia di } \\
\text { Uttarakhand } \\
\text { Negara India. }\end{array}$ & 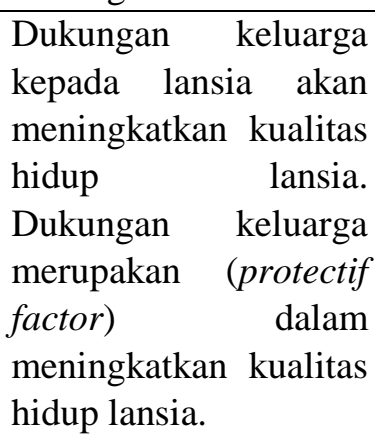 \\
\hline 8 & $\begin{array}{l}\text { Harkirat } \mathrm{K}, \\
\text { Harleen } \mathrm{K}, \\
\text { Mahalingam } \\
\text { V tahun } 2015\end{array}$ & $\begin{array}{l}\text { Deskriptif } \\
\text { exploratory } \\
\text { dengan } \\
\text { kuantitatif dan } \\
\text { kualitatif }\end{array}$ & $\begin{array}{l}\text { Kuesioner prediktor } \\
\text { dukungan keluarga dan } \\
\text { kuesioner kualitas hidup } \\
\text { lansia (QOL) }\end{array}$ & $\begin{array}{l}213 \text { orang } \\
\text { lansia di } \\
\text { Uttarakhand } \\
\text { Negara India. }\end{array}$ & $\begin{array}{lr}\text { Faktor seperti jenis } \\
\text { kelamin, pendidikan, } \\
\text { kemandirian } & \text { finansial, } \\
\text { dan ransian } & \text { dukungan } \\
\text { keluarga } & \text { yang } \\
\text { menentukan kualitas } \\
\text { hidup orang tua. } \\
\text { Demikian } & \text { pula, } \\
\text { pendidikan, kekayaan, } \\
\text { dan } & \text { dukungan } \\
\text { keluarga } & \text { adalah } \\
\text { prediktor } & \text { untuk } \\
\text { dukungan } & \text { keluarga } \\
\text { lansia. } & \end{array}$ \\
\hline
\end{tabular}




\begin{tabular}{|c|c|c|c|c|c|}
\hline 9 & $\begin{array}{l}\text { Khorni SA tahun } \\
2017\end{array}$ & $\begin{array}{l}\text { Penelitian } \\
\text { korelasional } \\
\text { menggunakan } \\
\text { desain cross } \\
\text { sectional }\end{array}$ & $\begin{array}{l}\text { Kuesioner } \\
\text { dukungan keluarga } \\
\text { dan kuesioner } \\
\text { kualitas hidup } \\
\text { lansia }\end{array}$ & $\begin{array}{l}100 \text { orang } \\
\text { lansia di } \\
\text { Gonilan, } \\
\text { Kartosuro, } \\
\text { Sukoharjo, } \\
\text { Jawa Tengah, } \\
\text { Indonesia. }\end{array}$ & $\begin{array}{lr}\begin{array}{l}\text { Ada } \\
\text { dukungan }\end{array} & \begin{array}{r}\text { hubungan } \\
\text { keluarga } \\
\text { terhadap } \\
\text { hualitas } \\
\text { hidup lansia } \\
\text { dengan }\end{array} \\
\text { psikologis, } & \text { fisik, } \\
\text { sosial dan } & \text { domain } \\
\text { lingkungan } & \\
\end{array}$ \\
\hline 10 & $\begin{array}{l}\text { Yusselda } \quad \text { M, } \\
\text { Wardani IY tahun } \\
2017\end{array}$ & $\begin{array}{l}\text { Deskriptif } \\
\text { korelatif cross } \\
\text { sectional }\end{array}$ & $\begin{array}{l}\text { Kuesioner } \\
\text { modifikasi } \\
\text { dukungan keluarga } \\
\text { dan kualitas hidup } \\
\text { menggunakan } \\
\text { WHOQOL- BREF. }\end{array}$ & $\begin{array}{l}84 \text { orang } \\
\text { lansia di Beji, } \\
\text { Depok, } \\
\text { Kendal, Jawa } \\
\text { Tengah, } \\
\text { Indonesia. }\end{array}$ & $\begin{array}{l}\text { Terdapat hubungan } \\
\text { dukungan emosional, } \\
\text { penghargaan, dan } \\
\text { instrumental keluarga } \\
\text { dengan kualitas hidup }\end{array}$ \\
\hline
\end{tabular}

Penelitian di India terhadap 213 lansia di Uttarakhand Negara India diperoleh hasil dukungan keluarga kepada lansia akan meningkatkan kualitas hidup lansia. Dukungan keluarga merupakan (protectif factor) dalam meningkatkan kualitas hidup lansia (Harkirat, Harleen, Mahalingam, 2015).

Penelitian di India terhadap 213 orang lansia di Uttarakhand Negara India diperoleh hasil Faktor seperti jenis kelamin, pendidikan, kemandirian finansial, dan dukungan keluarga yang menentukan kualitas hidup orang tua. Demikian pula, pendidikan, kekayaan, dan dukungan keluarga adalah prediktor untuk dukungan keluarga lansia (Harkirat, Harleen, Mahalingam, 2015).

Penelitian di Indonesia terhadap 100 orang lansia di Gonilan, Kartosuro, Sukoharjo, Jawa Tengah, Indonesia diperoleh hasil ada hubungan bermakna antara dukungan keluarga terhadap kualitas hidup lansia pada domain fisik, psikologis, domain sosial dan domain lingkungan (Khorni, 2017).

Penelitian di Indonesia terhadap 84 orang lansia di Beji, Depok, Kendal, Jawa Tengah, Indonesia diperoleh hasil ada hubungan antara dukungan emosional, penghargaan, dan instrumental keluarga dengan kualitas hidup (Yusselda, Wardani, 2017).

Keluarga menjadi tempat untuk berinteraksi, saling bergantung dengan anggota yang lain dalam mendapatkan dukungan secara emosional, instrumental, informasi dan manfaat. Manusia adalah makhluk sosial yang akan selalu terlibat berhubungan dan ketergantungan yang merupakan bentuk dukungan dengan yang lain. Dukungan yang diberikan dapat berupa dukungan positif ataupun dukungan negatif. Bentuk dukungan positif dapat memberikan motivasi ke arah yang lebih baik, tetapi dukungan negatif akan berdampak buruk (Suwarni, Soemanto, Sudiyanto, 2018).

Dukungan dari keluarga yang berbentuk positif akan berpengaruh terhadap aktivitas kehidupan sehari-hari, kondisi fisik dan kondisi mental. Berdampak kepada semangat dengan pekerjaannya untuk mencapai tujuan hidup, sehingga hasilnya akan menjadi maksimal. Namun, dukungan keluarga yang negatif akan menyebabkan stres, ketidaknyamanan, kemalasan untuk berperilaku, sehingga hasilnya tidak maksimal atau gagal bahkan terkadang 
menyebabkan stres dan keputusasaan (Suwarni, Soemanto, Sudiyanto, 2018).

Dukungan keluarga sangat diperlukan oleh lansia dalam sepanjang hidupnya. Anggota keluarga sangat berperan dalam merawat lansia, dengan cara bentuk kasih sayang, berhubungan dan berkomunikasi, membantu penyelesaian masalah yang ada, dukungan untuk memaksimalkan terjadinya kepuasan hidup. Kepuasan dalam hidup akan muncul dari perasaan yang tenang dan nyaman (Suwarni, Soemanto, Sudiyanto, 2018).

Keluarga menjadi tempat untuk memberikan dukungan emosional, sosial dan ekonomi. Seiring waktu seorang lansia akan mengalami perubahanperubahan dalam kehidupannya anatar lain : kesehatan, pendapatan, kegiatan sosial dan sebagainya. Sebagian besar lansia akan mengalami ketergantungan dengan keluarga, sehingga dukungan keluarga sangat dibutuhkan untuk perawatan seoarang lansia (Harkirat, Harleen, Mahalingam, 2015).

Keluarga sangat dibutuhkan oleh lansia dalam membantu lansia untuk memenuhi berbagai macam kebutuhan kehidupan sehari-hari, hal ini akan terjadi saat lansia sakit. Keluarga dibutuhkan lansia untuk pergi memeriksakan kesehatan ataupun berobat secara teratur. Berbagai bentuk perhatian yang diberikan keluarga ini diharapkan akan memotivasi lansia dalam meningkatkan kualitas hidupnya (Yusselda, Wardani, 2017).

Dukungan keluarga dapat dalam bentuk bantuan oleh keluarga lain yang akan menyediakan kenyamanan berupa fisik dan psikologis untuk orang lain ketika dalam situasi yang penuh tekanan (Maryam, Resnayati, Riasmini, Sari, 2018).

Untuk meningkatkan kualitas hidup lansia diharapkan pemerintah dan pihak lembaga sosial untuk mengadakan suatu kegiatan-kegiatan yang dapat meningkatkan harga diri dari lansia dan memberikan arahan untuk meningkatkan hubungan yang baik dengan keluarga (Harkirat, Harleen, Mahalingam, 2015).

Dukungan keluarga adalah anggota keluarga lain memberikan bantuan dalam bentuk motivasi dan memberikan kenyamanan. Lansia sangat membutuhkan dukungan keluarga untuk meningkatkan kualitas hidup mereka. Semua anggota keluarga sebagai lembaga sosial terkecil di masyarakat bertugas dan berkewajiban memperhatikan dan memberikan dukungan keluarga kepada lansia (Kadarwati, Soemanto, Murti, 2017).

\section{SIMPULAN}

Dukungan keluarga merupakan supporting factors atau faktor pendukung yang berpengaruh terhadap perilaku, gaya hidup dari lansia. Peran penting keluarga dalam konsep sehat sakit anggota keluarga lansia saat keluarga memberikan perawatan secara langsung kepada anggota keluarganya yang sakit sehingga keluarga adalah sistem pendukung yang akan berpengaruh pada peningkatan kualitas hidup lansia dalam bentuk fisik, psikologis, sosial, dan lingkungan. 


\section{DAFTAR PUSTAKA}

Beard J, Biggs S, Bloom D, Fried L, Hogan P, Kalache A, Olshansky S, 2012. Global Population Ageing: Peril or Promise. PGDA Working Paper No. 89. http://www.hsph.harvard.edu/pgda/working.htm

de Araújo AA, Rebouças Barbosa RA, de Menezes MS, de Medeiros II, de Araújo RF Jr, de Medeiros CA, 2016. Quality of Life, Family Support, and Comorbidities in Institutionalized Elders With and Without Symptoms of Depression. Psychiatr Q. 2016 Jun;87(2):281-91. doi: 10.1007/s11126-015-9386-y.

Fadilah N, Bachri S, Sutrisno, Angelia I, 2015. Hubungan Dukungan Keluarga Dengan Kunjungan Lansia Ke Posyandu Lansia Di Posyandu Bugenvil 50 Desa Gugut Kabupaten Jember. Jurnal kesehatan dr. Soebandi Vol. 3 No. 2.

Harkirat K, Harleen K, Mahalingam V, 2015. Perceived Family Support and Quality of Life of Elderly Population. International Journal of Nursing Education Year : 2015, Volume : 7, Issue : 4. First page : (91) Last page : (97). Print ISSN : 0974-9349. Online ISSN : 0974-9357. Article DOI : 10.5958/0974-9357.2015.00200.7.

Harkirat K, Harleen K, Mahalingam V, 2015. Factors Determining Family Support And Quality Of Life Of Elderly Population. International Journal of Medical Science and Public Health. 4.8 (Aug. 2015): p1049+.DOI: http://dx.doi.org/10.5455/ijmsph.2015.21012015220.

Copyright: COPYRIGHT 2015 Dipika Charan. http://www.ijmsph.com/

Kadarwati, Soemanto RB, Murti B, 2017. The Influence of Family Support, Social Capital, Self Efficacy, Education, Employment, Income, and Residential Status on the Quality of Life among the Elderly in Salatiga, Central Java. Journal of Epidemiology and Public Health (2017), 2 (1) : 58-69. https://doi.org/10.26911/ jepublichealth.2017.02.01.06 58.

Khorni SA, 2017. Hubungan Antara Dukungan Keluarga Dengan Kualitas Hidup Lansia Di Desa Gonilan Kecamatan Kartasura Kabupaten Sukoharjo. Publikasi Ilmiah. Program Studi S1 Keperawatan Fakultas Ilmu Kesehatan Universitas Muhammadiyah Surakarta 2017.

Liu H, Xiao Q, Cai Y, Shuzhuo Li, 2015. The quality of life and mortality risk of elderly people in rural China: the role of family support. Asia Pac J Public Health. 2015 Mar;27(2):NP2232-45. doi: 10.1177/1010539512472362.

Maryam RS, Resnayati Y, Riasmini NM, Sari CWM, 2018. Effect of Family Support Intervention towards Quality of Life with Elderly's Hypertension in Community. Padjadjaran Nursing Journal (Jurnal Keperawatan Padjadjaran) ISSN 2338-5324 (print) ISSN 2442-7276 (online) Online di http://jkp.fkep.unpad.ac.id DOI : $10.24198 / \mathrm{jkp}$.

Moher D, Liberati A, Tetzlaff J, Altman DG, 2009. Academia and Clinic Annals of Internal Medicine Preferred Reporting Items for Systematic Reviews and Meta-Analyses : Annals of Internal Medicine, 151(4), 264-269. https://doi.org/10.7326/0003-4819151-4-200908180-00135. 
Silva VdL, Medeiros CACXd, Guerra GCB, Ferreira PHA, Júnior RFdA, 2017. Quality of Life, Integrative Community Therapy, Family Support, and Satisfaction with Health Services Among Elderly Adults with and without Symptoms of Depression. Psychiatr Q. 2017 Jun;88(2):359-369. doi: 10.1007/s11126-016-9453-Z.

Suwarni S, Soemanto RB, Sudiyanto A, 2018. Effect of Dementia, Family Support, Peer Support, Type of Residence, and Marital Status on Quality of Life of the Elderly in Surakarta, Central Java. Journal of Epidemiologi and Public Health (2018), 3(1): 8394 https://doi.org/10.26911/jepublichealth.2018.03.01.07.

Tel H, 2013. Sleep Quality and Quality of Life among the Elderly People. Neurology, Psychiatry and Brain Research, 48-52.

Wahdah, Nurul, 2011. Menaklukan Hipertensi dan Diabetes. Yogyakarta: Multipress.

Yuliati A, Baroya N, Ririanty M, 2014, Perbedaan Kualitas Hidup Lansia yang Tinggal di Komunitas dengan di Pelayanan Sosial Lanjut Usia. Jember: e-Jurnal Pustaka Kesehatan, vol. 2 (no. 1) Januari 2014.

Yusselda M, Wardani IY, 2017. Dampak Dukungan Keluarga Terhadap Kualitas Hidup Lansia. Jurnal Keperawatan Volume 8 No 1, Hal 9 - 13, Maret 2016 Sekolah Tinggi Ilmu Kesehatan Kendal ISSN : Cetak 2085-1049. 